\title{
Assessment of the Knowledge and Practices about Diabetes Mellitus among Governmental School Teachers in Uglat Asugour, Qassim, Saudi Arabia
}

\author{
Faisal Ibrahim Almohaileb ${ }^{1}$, Omar Ahmed Alturki ${ }^{2}$, Ali Mohammed Alsudays ${ }^{2}$, Ibrahim Abdulkareem Aldakheel ${ }^{2}$, \\ Ali Abdulrahman Alarfaj ${ }^{2}$
}

${ }^{1}$ Department of Family and Community Medicine, College of Medicine, Qassim University, Buraydah, Saudi Arabia

${ }^{2}$ College of Medicine, Qassim University, Buraydah, Saudi Arabia

Corresponding author: Omar Ahmed Alturki, omaralturki13@gmail.com

Received 02 January 2019;

Accepted 09 January 2019;

Published 12 January 2020

\begin{abstract}
Background: Knowledge and practice about diabetes mellitus (DM) are crucial among school teachers as they could not only be diabetic, dealing with diabetic children/adolescents, but they also share the responsibility of improving the awareness and practice regarding the epidemic disease in our community. Objectives: This cross-sectional study was done in a rural area, Uglat Asugour, to determine the awareness and practices considering DM among governmental school teachers, and, their relationship with teachers' sociodemographic, life style, and anthropometric indices, and, their history of DM. Furthermore, the study aimed to compare between awareness and practice among study participants and to identify risk factors and their relationship. Participants and Methods: The study anonymously enrolled all the voluntarily willing elementary, middle and high school male teachers during April 2018. Data collection tool was a structured self-administered Arabiclanguage questionnaire that contained a part for collection of the sociodemographic, life style and anthropometric characteristics and diabetes medical history of participants, part 2 has 15 items concerned with knowledge, and, part 3 has 4 items concerned with practice regarding DM. Absentees for any reason were excluded. Results: A total of 171 teachers were targeted. The response rate was $91.8 \%$ meaning that 157 teachers were included. Their age was $33.5 \pm 06.4$ (mean $\pm \mathrm{SD}$ ) years. $5.1 \%$ were diabetic and $31.8 \%$ of them were having diabetic student(s). The knowledge regarding DM among them showed that $141(89.8 \%)$ had good knowledge and only $16(10.2 \%)$ were having poor knowledge. In regard to practice, $106(67.5 \%)$ teacher were having good practice while $51(32.5 \%)$ were having poor practice. Diabetic teachers and those with a family member with DM, ex-teachers on administrative jobs and teachers at elementary schools scored better than the others in both aspects. Conclusion: comparable to national and international reports, the majority of the targeted school teachers showed a good knowledge and exhibited a good practice regarding DM. Because the country suffers a diabetes epidemic, knowledge and practice require furthering programs that target school teacher in particularly.
\end{abstract}

Keywords: School teachers, Diabetes mellitus, Knowledge, Practice, Saudi Arabia.

\section{Introduction}

Diabetes mellitus (DM) is a common non-communicable disease with a prevalence of $8.3 \%$ worldwide and of $23.9 \%$ in Saudi Arabia. ${ }^{[1]}$ The disease has a functional or quantitative insulin deficiency leading to hyperglycemia. There are many risk factors for the disease; the strongest is the family history of DM. ${ }^{[2]}$ BMI, fat percentage, tobacco use, and even race is considered a risk factor for DM. ${ }^{[3,4]}$ Moreover, DM can lead to serious multisystemic complications that include cardiovascular, renal, ophthalmic, and neural complications. ${ }^{[5-8]}$ Fortunately, DM can be averted and/or its complications delayed by following a healthy lifestyle such as balanced diet, regular physical activity and achieving normal body mass index, and, the disease vigilance with good knowledge and practice for better management and quality of life. ${ }^{[9]}$

Many studies evaluated the awareness of DM in the general population. A study in Qassim region found that $63.4 \%$ of the general population were aware of the risk factors and $80.8 \%$ were aware about the symptoms of DM. ${ }^{[10]}$ Another Pakistani study found that most of the general population participants had a moderate knowledge of DM, where, being female, living in urban areas, being of high socioeconomic status and having a better education are associated with better knowledge of DM. ${ }^{[11]}$ A study about diabetes knowledge and attitude included 3104 adults from the general population in a Bangladeshi rural area found that $93 \%$ of the participants heard about DM, and sedentary lifestyle was a known risk factor for $50 \%$ of them. Younger age $(<35)$, male gender and higher educational level were associated with better 
knowledge which deemed as poor in these rural areas. ${ }^{[12]}$ Among Kuwaiti governmental employees, only $6.1 \%$ correctly answered all questions about general information regarding DM while the rest could only answer half or less. ${ }^{[13]}$ A survey distributed among the visitors of the Primary healthcare Centers (PHCs) in AlKhobar, Saudi Arabia, showed that only $42 \%$ and $41.7 \%$ of the sample knew about DM risk factor and prevention, respectfully. ${ }^{[14]}$

The school teachers' knowledge about DM have been assessed in many studies. In a cross-sectional study done in among female teachers from Alkhobar city $73 \%$ claimed that they know about hypoglycemic symptoms but only half correctly answered related questions. ${ }^{[15]}$ Another study assessing the knowledge, management and attitude toward diabetic care among intermediate school teachers in Riyadh city had found that $78 \%$ of the participants had medium knowledge about DM. The least known was the normal ranges of glucose and knowledge about the treatment of diabetes was known to only $18.6 \%$ of the teachers. ${ }^{[16]}$ A Turkish study assessed the knowledge of diabetes mellitus among 1054 secondary school teachers and found that $47.6 \%$ of them were having a moderate knowledge of the disease, while the majority of the remaining (32.4\%) were having poor knowledge. However, teachers with a diabetic family member had the best knowledge. ${ }^{[17]}$

Patients with diabetes have to give more effort in maintaining their healthy lifestyle. Vigilance of the disease along with other modalities are necessary in helping patients to take care of their health and increase their quality of life. Knowledge about diabetes is crucial among school teachers as they could be not only dealing with diabetic children/adolescents but also share the responsibility of spreading awareness and better practice regarding the disease. This study was planned to determine the awareness and practices considering diabetes among governmental school teachers in the rural Qassim area of Uglat Asugour using a validated previously published structured questionnaire.

\section{Participants and Methods}

Setting: The study was approved by regional committee of bioethics (REC) at Qassim region (approval number: 560203 at 2018/4/28). The survey was distributed to the consented volunteering teachers in all governmental male school on Uglat Asugour during April 2018. The study was including all targeted population so it manages to involve 157 male teachers out of 171 teachers targeted (response rate was 91.8\%). They comprised current and ex-teachers who are currently working in administrative jobs such as principles.

Data collection tool: a paper-based questionnaire was developed by A. Mohieldein ${ }^{[15]}$ which was adopted, modified and pre-piloted with 20 teachers to be suitable for targeted population. The first part of the questionnaire was for collection of the relevant sociodemographic, life style and anthropometric characteristics and diabetes medical history of the participants. The part of the data collection tool that evaluated knowledge about DM was composed of fifteen questions with "No", "Yes" and "I don't know" as the answer options. Points were given to the selected option in which 2 points were given for the correct answer, 1 for the incorrect answers and 0 for the option "I don't know". Final score ranging from 0 to 30 points were calculated for each response. Based on the final score, level of knowledge was classified into: Poor knowledge with a score of 0-15 points and as good knowledge with a score of 16-30. The portion that assessed the practice regarding DM was composed of four questions with "No or decrease blood sugar", "Yes or increase blood sugar" and "I don't know" as the answer options. Similarly, 2 points were given for the correct answer, 1 for the incorrect answers and 0 for the option "I don't know". Final score ranging from 0 to 8 points was calculated for each response. Poor practice scored $0-4$ points and good practice score is $5-8$ points.

Statistical analysis: The data were analyzed using Statistical Packages for Social Sciences (SPSS) version 21. A p cut off value of $\leq 0.05$ at $95 \%$ CI was considered significant. Stratified for their sociodemographic, life style and anthropometric characteristics, and, diabetes medical history of participants, the association with knowledge and practice regrading diabetes was analyzed using logistic regression analysis, Chi-square test and independent t-test as appropriate.

\section{Results}

Sociodemographic, life style and anthropometric characteristics of participants had been presented in Table 1. Numbers and percentages were used to summarize all categorical variables and mean \pm SD were applied for all continuous variables of one hundred and fifty-seven (157) who were voluntarily enrolled in this study. Mean age of the patients was 33.5 years (SD 06.4), mean weight was $76.2 \mathrm{~kg}$ (SD 21.2), while the mean height was 167.8 $\mathrm{cm}$ (SD 08.8) and the Body Mass Index (BMI) was $27.1 \mathrm{~kg} / \mathrm{m} 2$ (SD 07.6). BMI has been classified into three categories such as; underweight to normal $(16-24.9 \mathrm{~kg} / \mathrm{m} 2)$, Overweight $(25-29.9$ $\mathrm{kg} / \mathrm{m} 2)$ and Obese $(\geq 30 \mathrm{~kg} / \mathrm{m} 2)$. Based on the results, it shows underweight to normal were $62(43.1 \%)$, Overweight were 52 $(36.1 \%)$ and Obese were $30(20.8 \%)$. Of the 157 participants 132 $(84.1 \%)$ were non-smoker, while $13(08.3 \%)$ were smoker and 12 $(07.6 \%)$ were ex-smoker. With regards to physical activity of the teachers for at least 30 minutes, forty one percent had exercise for at least 1 - 2 days a week, twenty percent of them achieved exercise for at least $3-4$ days a week, four percent of them carried out exercise for at least 5 - 6 days a week and another four percent doing exercise daily while twenty nine percent of them never exercise. Majority of the teachers teaches elementary school as 71 $(45.2 \%), 43(27.4 \%)$ of the teachers teaches middle school, while $23(14.6 \%)$ were teaches at high school and $20(12.7 \%)$ were previously teaching. These 20 participants who were previously teaching had been either promoted in a higher position or working with different position within the institution. More than a half of the teachers were in the field of literature with 83 (52.9\%) while 74 $(47.1 \%)$ were in the field of scientific. Only five percent of the teachers were diabetic while thirty-one percent of them had diabetic student. Forty-seven percent of the teachers stated that their parents have diabetes, nine percent of them said their brother or sister have diabetes while only one percent of the said their son or wife have diabetes. The prevalence of knowledge of teachers regarding DM shows, 141 (89.8\%) for good knowledge and only $16(10.2 \%)$ were poor knowledge. Considering the practices, the prevalence revealed that $106(67.5 \%)$ were of good practices while $51(32.5 \%)$ were of poor practices.

Table 1: Descriptive analysis for the socio-demographic, life style and anthropometric characteristics and diabetes medical history of the study population $(n=157)$. Data shown are mean \pm SD and frequencies; $n(\%)$.

\begin{tabular}{|l|l|}
\hline Study Variables & Mean \pm SD or n $(\%)$ \\
\hline Age in years $($ mean \pm SD) & $33.5 \pm 06.4$ \\
\hline
\end{tabular}




\begin{tabular}{|c|c|}
\hline Weight, kg & $76.2 \pm 21.2$ \\
\hline Height, cm & $167.8 \pm 08.8$ \\
\hline \multicolumn{2}{|l|}{ BMI, $\mathrm{kg} / \mathrm{m}^{2}$} \\
\hline Underweight - Normal & $43(20.8 \%)$ \\
\hline Overweight & $62(43.1 \%)$ \\
\hline Obese & $52(36.1 \%)$ \\
\hline \multicolumn{2}{|l|}{ Smoking status } \\
\hline Smoker & $13(8.3 \%)$ \\
\hline Non-Smoker & $132(84.1 \%)$ \\
\hline Ex-smoker & $12(7.6 \%)$ \\
\hline \multicolumn{2}{|l|}{ Physical activity at least 30 minutes } \\
\hline Daily & $7(4.5 \%)$ \\
\hline $5-6$ days per week & $7(4.5 \%)$ \\
\hline $3-4$ days per week & $32(20.4 \%)$ \\
\hline $1-2$ days per week & $65(41.4 \%)$ \\
\hline Never & $46(29.3 \%)$ \\
\hline \multicolumn{2}{|l|}{ The class you teach: } \\
\hline Ex-teacher & $20(12.7 \%)$ \\
\hline Elementary school & $71(45.2 \%)$ \\
\hline Middle school & $43(27.4 \%)$ \\
\hline High school & $23(14.6 \%)$ \\
\hline What specialty do you teach? Scientific/Literature & $74(47.1 \%) / 83(52.9 \%)$ \\
\hline \multicolumn{2}{|l|}{ Are you diabetic? } \\
\hline Yes & $8(5.1 \%)$ \\
\hline No & $145(92.4 \%)$ \\
\hline I don't know & $4(2.5 \%)$ \\
\hline \multicolumn{2}{|l|}{ Do you have a diabetic student? } \\
\hline Yes & $50(31.8 \%)$ \\
\hline No & $84(53.5 \%)$ \\
\hline I don’t know & $23(14.6 \%)$ \\
\hline \multicolumn{2}{|l|}{ Family history of diabetes } \\
\hline Parents & $74(47.1 \%)$ \\
\hline Son & $2(1.3 \%)$ \\
\hline Wife & $2(1.3 \%)$ \\
\hline Sister/Brother & $15(9.6 \%)$ \\
\hline Knowledge: Poor/Good & $16(10.2 \%) / 141(89.8 \%)$ \\
\hline Practice regarding diabetes: Poor/Good & $51(32.5 \%) / 106(67.5 \%)$ \\
\hline
\end{tabular}

Figure 1 describes the sources of information of teachers regarding diabetes. Sixty-six percent of them had friends and relatives as their primary sources, fifty-six percent utilized internet, fifty-five percent used social media, forty percent said media, thirty-seven percent had chosen health institutes workers and nineteen percent picked book and magazine.

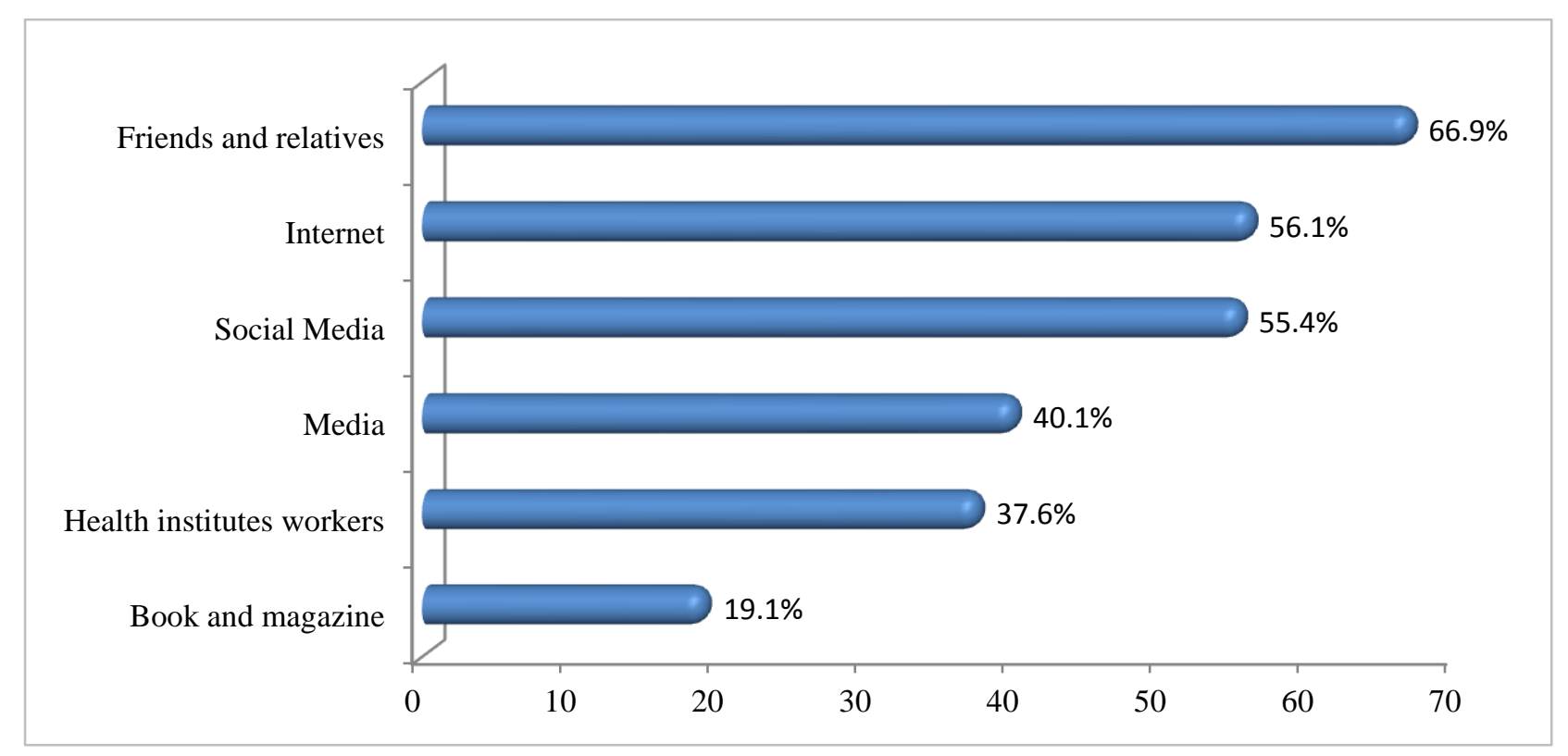

Figure 1: Distribution of the sources of information about diabetes among targeted school teachers. 
The part of the data collection tool that evaluated knowledge items about DM is presented in Table 2, and those assessing the practice regarding DM related items are presented in Table 3.

Table 2: School teachers' knowledge about diabetes mellitus (DM; $n=157)$. Data shown are frequencies; $n(\%)$.

\begin{tabular}{|c|c|c|c|}
\hline Statement & Yes & No & I don't know \\
\hline 1. Have you heard about DM & $151(96.2 \%)$ & $4(2.5 \%)$ & $2(1.3 \%)$ \\
\hline 2. $\quad$ Is DM a curable disease & $37(23.6 \%)$ & $68(43.3 \%)$ & $52(33.1 \%)$ \\
\hline 3. Is DM an inherited disease & $106(67.5 \%)$ & $25(15.9 \%)$ & $26(16.6 \%)$ \\
\hline 4. DM is about blood sugar being elevated & $122(77.7 \%)$ & $18(11.5 \%)$ & $17(10.8 \%)$ \\
\hline 5. DM is infectious disease & $2(1.3 \%)$ & $148(94.3 \%)$ & $7(4.5 \%)$ \\
\hline 6. $\quad$ DM is related to obesity & $125(79.6 \%)$ & $20(12.7 \%)$ & $12(7.6 \%)$ \\
\hline 7. DM disease starts in patients more than 40 years old & $105(66.9 \%)$ & $36(22.9 \%)$ & $16(10.2 \%)$ \\
\hline 8. Continuous feeling of thirst is a symptom of DM & $119(75.8 \%)$ & $8(5.1 \%)$ & $30(19.1 \%)$ \\
\hline 9. Increasing frequency of urination is a DM symptom & $144(91.7 \%)$ & $2(1.3 \%)$ & $11(7.0 \%)$ \\
\hline 10. Slow wound healing is a DM symptom & $145(92.4 \%)$ & $2(1.3 \%)$ & $10(6.4 \%)$ \\
\hline 11. Fatigue is a DM symptom & $139(88.5 \%)$ & $4(2.5 \%)$ & $14(8.9 \%)$ \\
\hline 12. DM patient could have eye and vision problem & $133(84.7 \%)$ & $5(3.2 \%)$ & $19(12.1 \%)$ \\
\hline 13. DM patient could have kidney issue & $114(72.6 \%)$ & $11(7.0 \%)$ & $32(20.4 \%)$ \\
\hline 14. DM patient could have hypertension & $84(53.5 \%)$ & $23(14.6 \%)$ & $50(31.8 \%)$ \\
\hline 15. DM student can participate in school activity & $103(65.6 \%)$ & $33(21.0 \%)$ & $21(13.4 \%)$ \\
\hline
\end{tabular}

Table 3: School teachers' practice about diabetes mellitus (DM; $\mathbf{n}=157)$. Data shown are frequencies; $\mathbf{n}(\%)$.

\begin{tabular}{|c|c|}
\hline Statement & n $(\%)$ \\
\hline \multicolumn{2}{|c|}{ 1. Do you think diabetic student should have a special diet? } \\
\hline Yes & $14693.0 \%)$ \\
\hline No & $04(02.5 \%)$ \\
\hline I don't know & $07(04.5 \%)$ \\
\hline \multicolumn{2}{|c|}{ 2. In case a DM student has vomiting, abdominal pain and severe feeling of thirst, does he have: } \\
\hline Decrease blood sugar & $27(17.2 \%)$ \\
\hline Increase blood sugar & $61(38.9 \%)$ \\
\hline I don't know & $69(43.9 \%)$ \\
\hline \multicolumn{2}{|c|}{ 3. In case a DM student has palpitation, sweeting a lot and can't concentrate, does he have: } \\
\hline Decrease blood sugar & $79(50.3 \%)$ \\
\hline Increase blood sugar & $30(19.1 \%)$ \\
\hline I don’t know & $48(30.6 \%)$ \\
\hline \multicolumn{2}{|c|}{ 4. If it is available, will you join a special training program to learn how to deal with a DM student? } \\
\hline Yes & $128(81.5 \%)$ \\
\hline No & $18(11.5 \%)$ \\
\hline I don't know & $11(07.0 \%)$ \\
\hline
\end{tabular}

Table 4 presents the assessed relationship between level of knowledge and the sociodemographic, life style and anthropometric characteristics of participants. Chi-square test and independent t-test were used. Analysis revealed that among these, only level of practice regarding diabetes showed significant relationship ( $\mathrm{p}<0.001)$.

Table 4: Association between knowledge about diabetes and the participants' sociodemographic, life style and anthropometric characteristics and diabetes medical history $(n=157)$. Data shown are mean \pm SD and frequencies; $n(\%)$, and p value of chi-square test and independent t-test.

\begin{tabular}{|l|l|l|l|}
\hline \multirow{2}{*}{ Characteristics } & \multicolumn{2}{|l|}{ Level of Knowledge } & \multirow{2}{*}{ P value } \\
\cline { 2 - 4 } & Good $(\mathbf{n}=\mathbf{1 4 1})$ & Poor $(\mathbf{n}=\mathbf{1 6})$ & 0.440 \\
\hline Age, years & $33.5 \pm 6.2$ & $32.9 \pm 7.9$ & 0.308 \\
\hline Weight, kg & $75.9 \pm 19.1$ & $78.2 \pm 35.0$ & 0.130 \\
\hline Height, cm & $167.5 \pm 9.1$ & $169.7 \pm 4.8$ & \\
\hline BMI & & & \multirow{2}{*}{0.535} \\
\hline Normal and below & $54(87.1 \%)$ & $8(12.9 \%)$ & \\
\hline Overweight and obese & $75(90.4 \%)$ & $8(9.6 \%)$ & \multirow{2}{*}{0.338} \\
\hline Are you diabetic? & & & \\
\hline Diabetic & $8(100 \%)$ & 0 & \\
\hline Non-Diabetic & $130(89.7 \%)$ & $15(100 \%)$ & \\
\hline Smoking status & & & \multirow{2}{*}{0.756} \\
\hline Smoker & $12(92.3 \%)$ & $1(7.7 \%)$ & \\
\hline Non-Smoker & $129(89.6 \%)$ & $15(10.4 \%)$ & \\
\hline Practicing physical activity & & & \\
\hline
\end{tabular}




\begin{tabular}{|c|c|c|c|}
\hline Yes & $100(90.1 \%)$ & $11(9.9 \%)$ & \multirow{2}{*}{0.856} \\
\hline No & $41(89.1 \%)$ & $5(10.9 \%)$ & \\
\hline \multicolumn{4}{|l|}{ Teaching } \\
\hline Ex-teacher & $18(90.0 \%)$ & $2(10.0 \%)$ & \multirow{4}{*}{0.079} \\
\hline Elementary school & $68(95.8 \%)$ & $3(4.2 \%)$ & \\
\hline Middle school & $37(86.0 \%)$ & $6(14.0 \%)$ & \\
\hline High school & $18(78.3 \%)$ & $5(21.7 \%)$ & \\
\hline \multicolumn{4}{|c|}{ Level of practice regarding diabetes } \\
\hline Good & $102(96.2 \%)$ & $4(3.8 \%)$ & \multirow{2}{*}{$<0.001$} \\
\hline Poor & $39(76.5 \%)$ & $12(23.5 \%)$ & \\
\hline
\end{tabular}

Don't know has been excluded from the analysis.

Table 5 presents the relationship between level of practice regarding DM vs. the sociodemographic, life style and anthropometric characteristics of participants. The analysis revealed that among these variables the teacher's height $(p=0.017)$ and the nature of the students' grade the teacher is teaching to $(\mathrm{p}=0.010)$ had a significant relationship to level of practice regarding DM.

Table 5: Association between practice about diabetes and the participants' sociodemographic, life style and anthropometric characteristics and diabetes medical history $(n=157)$. Data shown are mean \pm SD and frequencies; $n(\%)$, and $p$ value of chi-square test and independent t-test.

\begin{tabular}{|c|c|c|c|}
\hline \multirow{2}{*}{ Characteristics } & \multicolumn{2}{|c|}{ Level of Practices } & \multirow{2}{*}{ P value ${ }^{\S}$} \\
\hline & $\operatorname{Good}(n=106)$ & Poor $(n=51)$ & \\
\hline Age, years & $33.5 \pm 06.5$ & $33.3 \pm 06.1$ & 0.822 \\
\hline Weight, kg & $74.7 \pm 17.9$ & $79.4 \pm 26.9$ & 0.410 \\
\hline Height, cm & $166.3 \pm 08.2$ & $170 \pm 09.0$ & 0.017 \\
\hline \multicolumn{4}{|l|}{ BMI } \\
\hline Normal and below & $41(66.1 \%)$ & $21(33.9 \%)$ & \multirow{2}{*}{0.746} \\
\hline Overweight and Obese & $57(68.7 \%)$ & $26(31.3 \%)$ & \\
\hline \multicolumn{4}{|l|}{ Are you diabetic? } \\
\hline Diabetic & $05(62.5 \%)$ & $03(37.5 \%)$ & \multirow{2}{*}{0.701} \\
\hline Non-diabetic & $45(31.0 \%)$ & $100(69.0 \%)$ & \\
\hline \multicolumn{4}{|l|}{ Smoking status } \\
\hline Smoker & $10(76.9 \%)$ & $03(23.1 \%)$ & \multirow{2}{*}{0.450} \\
\hline Non-Smoker & $96(66.7 \%)$ & $48(33.3 \%)$ & \\
\hline \multicolumn{4}{|c|}{ Practicing physical activity } \\
\hline Yes & $76(68.5 \%)$ & $35(31.5 \%)$ & \multirow{2}{*}{0.692} \\
\hline No & $30(65.2 \%)$ & $16(34.8 \%)$ & \\
\hline \multicolumn{4}{|l|}{ Teaching } \\
\hline Ex-teacher & $16(80.0 \%)$ & $04(20.0 \%)$ & \multirow{4}{*}{$0.010 * *$} \\
\hline Elementary school & $55(77.5 \%)$ & $16(22.5 \%)$ & \\
\hline Middle school & $24(55.8 \%)$ & $19(44.2 \%)$ & \\
\hline High school & $11(47.8 \%)$ & $12(52.2 \%)$ & \\
\hline
\end{tabular}

${ }^{8}$ Don't know has been excluded from the analysis.

Table 6 shows the logistic regression analyses estimating the factors among participants' sociodemographic, life style and anthropometric characteristics that influenced level of their knowledge regarding DM subdivided as good and poor. Analysis revealed that among these characteristics, teaching for elementary school (odds ratio $=6.296$ and $p=0.018$ ) and level of practices regarding diabetes (odds ratio $=0.127$ and $\mathrm{p}=0.001)$ had statistically significant effect.

Table 6: Regression analysis to predict good knowledge regarding diabetes from the sociodemographic, life style and anthropometric variables and diabetes medical history of the participating teachers $(n=157)$. Data shown are odds ratio $(\mathrm{OR}), 95 \%$ confidence interval (CI) and p value.

\begin{tabular}{|l|l|l|l|}
\hline Characteristics & OR & 95\% CI & P value \\
\hline Age, years & 1.015 & $0.934-1.103$ & 0.728 \\
\hline Weight, kg & 0.995 & $0.973-1.018$ & 0.678 \\
\hline Height, cm & 0.974 & $0.923-1.029$ & 0.355 \\
\hline BMI; Overweight and Obese vs. Normal and below & 0.720 & $0.254-2.038$ & 0.536 \\
\hline Smoking; Non-smoker vs. smoker & 1.395 & $0.169-11.497$ & 0.757 \\
\hline Practicing physical activity; No vs. Yes & 1.109 & $0.363-3.391$ & 0.856 \\
\hline Teaching & & & \\
\hline Ex-teacher & Ref & & 0.309 \\
\hline Elementary school & 2.500 & $0.428-14.607$ & $\mathbf{0 . 0 1 8}$ \\
\hline Middle school & 6.296 & $1.373-28.867$ & \\
\hline
\end{tabular}




\begin{tabular}{|l|l|l|l|}
\hline High school & 1.713 & $0.460-6.372$ & 0.422 \\
\hline Level of practice regarding diabetes; Good vs. Poor & 0.127 & $0.039-0.419$ & $\mathbf{0 . 0 0 1}$ \\
\hline
\end{tabular}

Logistic regression analysis estimated the investigated factors that influenced level of practice subdivided as good and poor. The relationship with height (odds ratio $=0.927$ and $\mathrm{p}=0.005$ ) and teaching at elementary school (odds ratio $=4.364$ and $\mathrm{p}=0.035$ ) and middle school (odds ratio $=3.750$ and $\mathrm{p}=0.009$ ) were found to be statistically significant.

Table 7: Regression analysis to predict good practice regarding diabetes from the sociodemographic, life style and anthropometric variables and diabetes medical history of the participating teachers $(n=157)$. Data shown are odds ratio $(\mathrm{OR}), 95 \%$ confidence interval (CI) and p value.

\begin{tabular}{|l|l|l|l|}
\hline Characteristics & OR & 95\% CI & P value \\
\hline Age, years & 1.006 & $0.954-1.061$ & 0.830 \\
\hline Weight, kg & 0.990 & $0.975-1.006$ & 0.217 \\
\hline Height, cm & 0.927 & $0.880-0.978$ & $\mathbf{0 . 0 0 5}$ \\
\hline BMI; Overweight and obese vs. normal and below & 0.891 & $0.442-1.796$ & 0.746 \\
\hline Smoking status; Nonsmoker vs. smoker & 1.667 & $0.438-6.339$ & 0.454 \\
\hline Practicing physical activity; No vs Yes & 1.158 & $0.560-2.396$ & 0.692 \\
\hline Teaching & & & \\
\hline Ex-teacher & Ref & \\
\hline Elementary school & 4.364 & $1.112-17.128$ & $\mathbf{0 . 0 3 5}$ \\
\hline Middle school & 3.750 & $1.394-10.088$ & $\mathbf{0 . 0 0 9}$ \\
\hline High school & 1.378 & $0.499-3.805$ & 0.536 \\
\hline
\end{tabular}

\section{Discussion}

We assessed the knowledge and practices regarding DM among diabetic and non-diabetic governmental school teachers from Qassim area and found that $89.8 \%$ of the teachers had a good level of knowledge while the rest of them were poorly aware. The level of awareness was better among diabetic teachers and those with a diabetic family member. Nationally, these results are consistent to another study from Qassim by Moheildein et al. that targeted the non-diabetic public and found that $67.4 \%$ of them had good general knowledge. ${ }^{[10]}$ Salem et al demonstrated a good knowledge prevalence of $75 \%$ among the general population at Riyadh. However, such knowledge was poorer among diabetic participants that contrasted with our findings. ${ }^{[18]}$ This may resort on our participants being educated and educators. Internationally, a Bangladeshi study reveal a prevailing average level of knowledge (68\%) among DM and non-DM patients (70\%). Poor knowledge among both was comparable to our results. ${ }^{[20]}$ Moderate level of knowledge about DM constituted $47.6 \%$ among a Turkish population while the knowledgeable (well-established and very well-established knowledge) represented $15.6 \% .^{[17]}$

The prevalence of good practice among teachers had $67.5 \%$ whereas poor practices had $32.5 \%$. However, good practice among diabetic/with a diabetic family member teacher was double the level among non-diabetic teachers (62.5 vs. $31 \%)$, likewise the prevalence of their poor practice (37.5 vs. $69.0 \%$ ). Lower figures were reported by Salem et al where $43 \%$ of respondents had good practices, with diabetic patients scoring slightly better practices (55 vs. $52 \%$, respectively). ${ }^{[18]}$ In the Bangladeshi study, good practice among non-DM participants scored $33 \%$ while their majority had moderate practice $(65 \%)$, while, the diabetic patients reported $16 \%$ good practice and a higher prevalence of moderate practice (72\%). ${ }^{[20]}$ More urbanized country of UAE showed that general practice considering DM scored good in $37.8 \%$, satisfactory in $46.9 \%$ and poor in $15.3 \%$ of the targeted population. ${ }^{[19]}$ The better figures in practice noted among our participants reflects their educated nature and the care of the health system to improve the awareness and practice against the epidemic disease.

Our school teachers sourced their information about DM in a decreasing weightage from friends/relatives, internet, social media and healthcare professionals. Mohieldein et al stated that relatives and friends were the unanimous source of information followed by the media. ${ }^{[10]}$ in the Turkish study on the opposing view, the context of general knowledge was the major source $(35.5 \%)$ whereas, TV accounted for $7.9 \%$ and healthcare professional accounted for $6.8 \%$. $^{[17]}$

We found a strong relationship between knowledge and practice, which means that the knowledge is translated into a good practice. There was a significant positive relationship between each of participants' height and nature of the class taught (elementary) vs. level of practice. Our study is among the few studied relationships between knowledge and practice regarding DM and the population sociodemographic, life style, anthropometric and diabetes medical history in Saudi Arabia. Commenting on the height relationship to knowledge, in our closed society, a taller person would have higher trust and so would be keener to make himself knowledgeable. Logistic regression analysis confirmed a positive relationship between teaching at elementary schools and knowledge about DM. The latter consequently improved the level of practice where a positive relationship amongst the two of them was found. This notation is rational since they are exposed them most to the youngest DM student patients. Moreover, participant's height, ex-teaching and teaching at elementary schools revealed significant effects towards good practice. Several published studies reported significant relationship between knowledge and practice regarding DM and sociodemographic data. ${ }^{[18-20]}$ However, Mohieldein et al could not predict good knowledge from the sociodemographic characteristics of his population. ${ }^{[15]}$

\section{Conclusion}

A majority of our participating school teacher had good knowledge and practice about DM. experiences ex-teachers on administrative jobs and teachers at elementary schools score the best amongst all. Diabetic participants and those living with a diabetic patient performed better compared to non-diabetic teachers. Although our population's scores in DM knowledge and practice are comparably good, the public community scores are expected to be lower. Therefore, furthering these scores is mandatory through education, PHCCs and healthcare campaigns. 


\section{Limitation}

This study had some limitations in collecting data. It didn't include female teacher as it was difficult to reach female section because the lack of female data collectors. Some School managers refused to distribute the survey because they believed it was impeding teachers' work and it wasn't important. Some teachers weren't in the school when the survey was distributed. Lack of facilities in the Ministry of Education for those wanting to apply their research in schools. The difficulty of distribution to some teachers because they do not believe in scientific research.

\section{Funding}

There was no funding from any institution

\section{Conflict of Interest}

No conflict of interest

\section{Acknowledgment}

We would like to thank the Deanship for Community Service at Qassim University for their helpful support in collecting the data of this study.

\section{References}

[1] Naeem Z. Burden of Diabetes Mellitus in Saudi Arabia. Int J Health Sci (Qassim), 2015;9(3).

[2] InterAct Consortium, Scott RA, Langenberg C, Sharp SJ, Franks PW, Rolandsson O, Drogan D, Ekelund U, et al. The link between family history and risk of type 2 diabetes is not explained by anthropometric, lifestyle or genetic risk factors: the $\{$ EPIC $\}-\{$ InterAct $\}$ study. Diabetologia, 2013;56(1):60-9.

[3] Chan JM, Rimm EB, Colditz GA, Stampfer MJ, Willett WC. Obesity, fat distribution, and weight gain as risk factors for clinical diabetes in men. Diabetes Care, 1994;17(9):961-9.

[4] Manson JE, Ajani UA, Liu S, Nathan DM, Hennekens $\mathrm{CH}$. A prospective study of igarette smoking and the incidence of diabetes mellitus among US male physicians. Am J Med., 2000;109(7):538-42.

[5] Emerging Risk Factors Collaboration, Sarwar N, Gao P, Seshasai SR, Gobin R, Kaptoge S, Di Angelantonio E, Ingelsson $\mathrm{E}$, et al. Diabetes mellitus, fasting blood glucose concentration, and risk of vascular disease: a collaborative meta-analysis of 102 prospective studies. Lancet (London, England), 2010;375(9733):2215-22.

[6] Saran R, Li Y, Robinson B, Ayanian J, Balkrishnan R, Bragg-Gresham J, Chen JT, Cope E, et al. US renal data system, 2014 Annual data report: Epidemiology of kidney disease in the United States. Am J Kidney Dis Off J Natl Kidney Found., 2015;66(1 Suppl 1):Svii, S1-305.

[7] Bourne RRA, Stevens GA, White RA, Smith JL, Flaxman SR, Price H, Jonas JB, et al. Causes of vision loss worldwide, 1990-2010: A systematic analysis. Lancet Glob Heal., 2013;1(6):e339-e49.

[8] Verrotti A, Prezioso G, Scattoni R, Chiarelli F. Autonomic neuropathy in diabetes mellitus. Front Endocrinol (Lausanne), 2014;5; 1-.

[9] Sahay BK, Sahay RK. Lifestyle modification in management of diabetes mellitus. J Indian Med Assoc., 2002;100(3):178-80.

[10] Mohieldein A, Alzohairy M, Hasan M. Awareness of diabetes mellitus among Saudi non-diabetic population in Al-Qassim region, Saudi Arabia. J Diabetes Endocrinol., 2011;2(2):14-9.

[11] Masood I, Saleem A, Hassan A, Umm-E-Kalsoom, Zia A, Khan AT. Evaluation of diabetes awareness among general population of Bahawalpur, Pakistan. Prim Care Diabetes, 2016;10(1):3-9.

[12] Islam FMA, Chakrabarti R, Dirani M, Islam MT, Ormsby G, Wahab M, Critchley C et al. Knowledge, attitudes and practice of diabetes in rural Bangladesh: the Bangladesh Population based Diabetes and Eye Study (BPDES). PLoS One, 2014;9(10):e110368; 1-.

[13] Abdulsalam AJ, Al-Daihani AE, Francis K. Diabetesrelated knowledge and preventative practices among government employees with diabetes in Kuwait. Sultan Qaboos Univ Med J., 2017;17(4):e444-e51.

[14] Aljoudi A, Taha AA. Knowledge of diabetes risk factors and preventive measures among attendees of a primary care center in eastern Saudi Arabia. Ann Saudi Med., 2009;29(1):15; 1 -.

[15] Abahussain NA, El-Zubier AG. Diabetes knowledge among self-reported diabetic female teachers: Alkhobar, Saudi Arabia. J Family Community Med., 2005;12(1):43-8.

[16] Abdel Gawwad ES. Teacher's knowledge, attitudes and management practices about diabetes care in Riyadh's schools. J Egypt Public Health Assoc., 2008;83(3-4):20522.

[17] Aycan Z, Önder A, Çetinkaya S, Bilgili H, Yıldırım N, Baş VN, Peltek Kendirci HN, et al. Assessment of the knowledge of diabetes mellitus among school teachers within the scope of the managing diabetes at school program. J Clin Res Pediatr Endocrinol., 2012;4(4):199203.

[18] Alzahrani S, Alshammari M, MushabbabAbdulaziaz M et al. Knowledge, attitude, and practice regarding diabetes mellitus among general public and diabetic patients in Riyadh, Saudi Arabia. Asian Journal of Pharmaceutics, 2018; Jan-Mar (Suppl);12 (1)

[19] Al-Maskari F, El-Sadig M, Al-Kaabi JM, Afandi B, Nagelkerke N, Yeatts KB. Knowledge, attitude and practices of diabetic patients in the United Arab Emirates. PLOS ONE, 2013; 8(1)

[20] Fatema K, Hossain S, Natasha K, Chowdhury HA, Akter J, Khan T, Ali L. Knowledge, attitude and practice regarding diabetes mellitus among nondiabetic and diabetic study participants in Bangladesh. BMC Public Health, 2017; 17:364; 1- . 


\section{Appendices}

- Consent form:

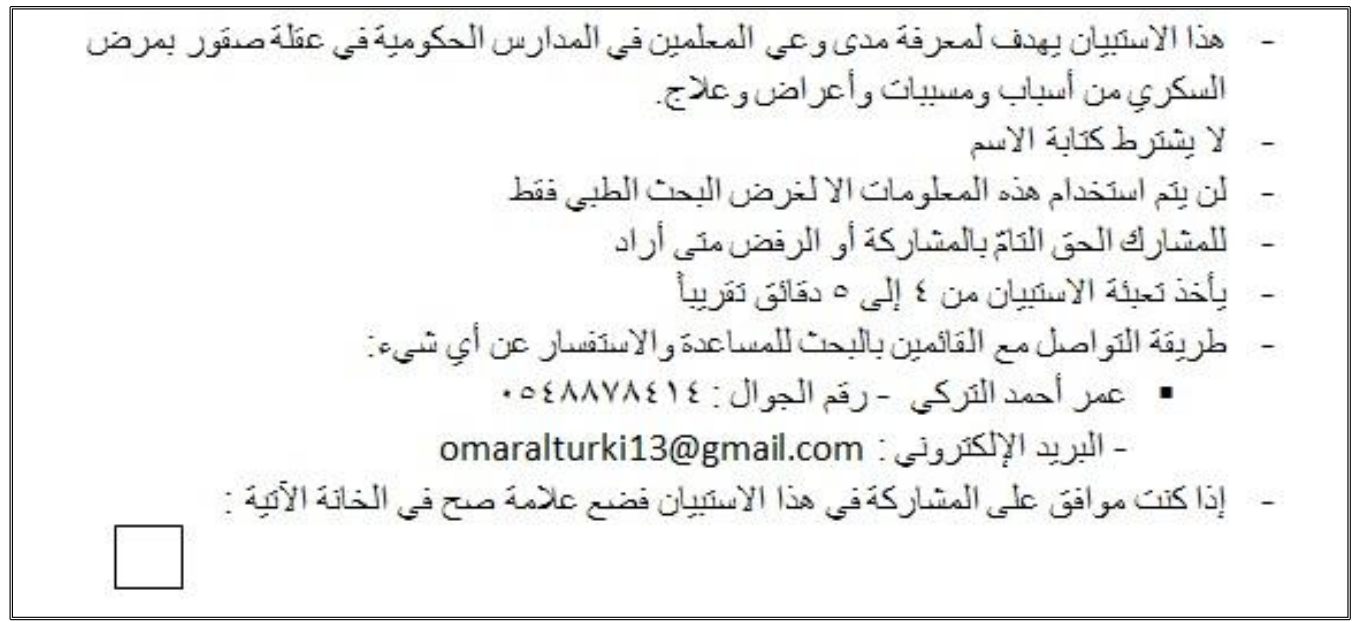

- Questionnaire

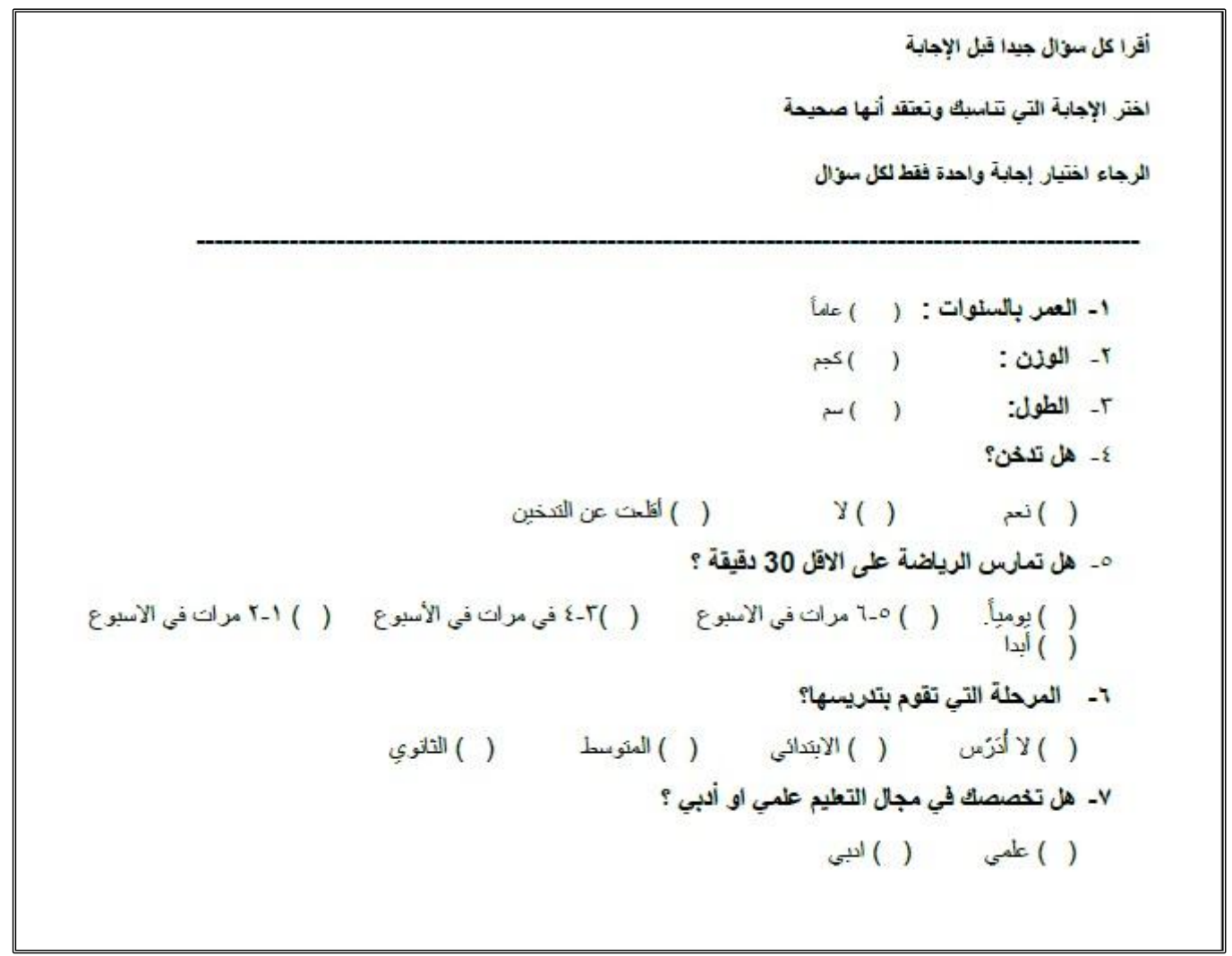




\section{الأسئلة الآتبة تتعلق بالسكرى:}

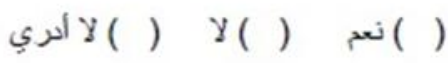

$$
\begin{aligned}
& \text { 1- ل أنت مصلب بالسكري؟ }
\end{aligned}
$$

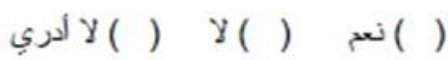

$$
\begin{aligned}
& \text { ז- هل سمت عن مرض السكري ؟ }
\end{aligned}
$$

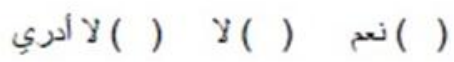

$$
\begin{aligned}
& \text { r- ـ هل مرض السكري يمكن الشفاء مذه تماما ؟ }
\end{aligned}
$$

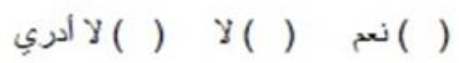

$$
\begin{aligned}
& \text { ع- - هل مرض السكري وراثي ؟ } \\
& \text { ( ) ( ) ( ) أدري } \\
& \text { ــ مرض السكري عبارة عن ارتفاع نسبة سكر الدم؟ } \\
& \text { ( ) ( ) أنع ( ) ( ) أدري } \\
& \text { T- . هل يعتبر مرض السكري من الامراض المعية؟ }
\end{aligned}
$$

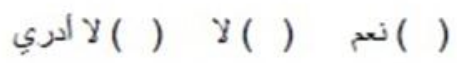

$$
\begin{aligned}
& \text { - - هل لمرض المكري علاقة بالسمثة ؟ }
\end{aligned}
$$

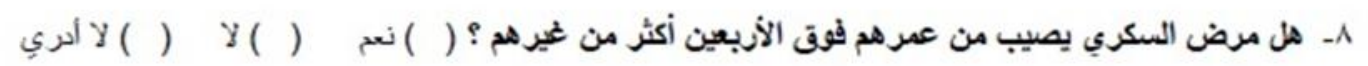

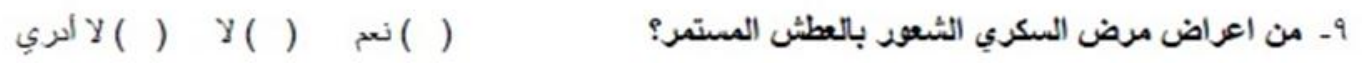

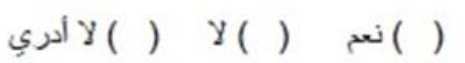

$$
\begin{aligned}
& \text {. ا- من اعرض السكري كثرة التبول ؟ } \\
& \text { ( ) أنعم ( ) ( ) أنري } \\
& \text { 1ا- من اعراض السكري بطء التنام الجروح ؟ } \\
& \text { ( ) أنعم ( ) ( ) أدري ( ) } \\
& \text { rا - من اعراض المكري الثعود بالتعب والضعف ؟ }
\end{aligned}
$$

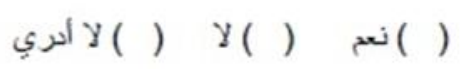

$$
\begin{aligned}
& \text { rا ـ قد يعاني مريض المكري بمشاكل في العين والابصار? } \\
& \text { ( ) ( ) أنعم ( ) ( ) أري } \\
& \text { ع ا ـ قد يعاني مريض المكري بمشاكل في الكلية ؟ } \\
& \text { ( ) ( ) أنع ( ) ( ) أري } \\
& 10 \text { ـ قد يعاني مريض السكري بارتفاع ضغط الدم ؟ } \\
& \text { ( ) النع ( ) أنري } \\
& 17 \text { - هل لليك طالب مصاب بالسكري؟ }
\end{aligned}
$$

V ا ـ هل تعتقد أن الطالب المصاب بالسكري يستطيع أن يشارك بالأشطة البلنية كأي طالب؟

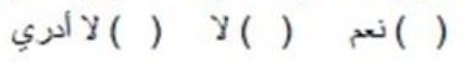

1 اـ - هل تعتقد أن الطالب المصاب بالسكري يحتاج لغذاء بنظام خاص؟ (اص

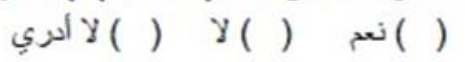


9 ا ـ في حال أن طلب السكري أصيب باستفراع وألم في البطن وعطش شديد هل هو انخفاض او ارتفاع في السكر؟

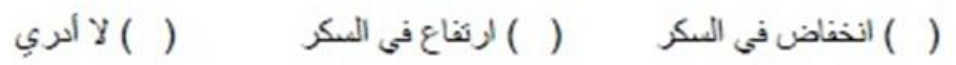

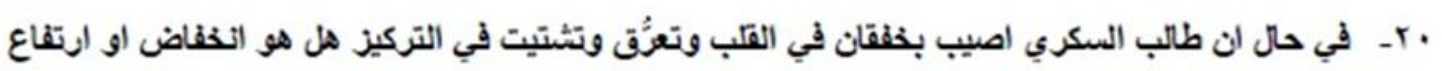
في السكر?

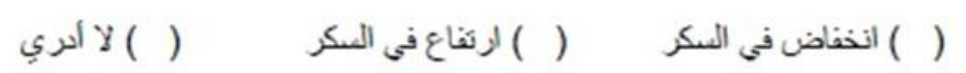

آ- لو أتيح لك دخول دودات وبرامج للتدريب على التعامل مع حالات السكري فهل ستهتم بالاضمام لها؟

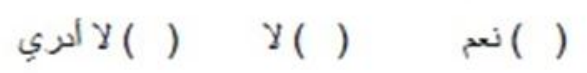

بr هل يعائي احد المذكورين أنداه من مرض المكري ؟

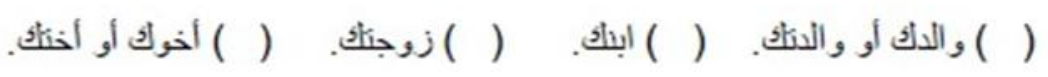

$$
\begin{aligned}
& \text { Tr ا اهم مصادر معظوماتك عن مرض السكري ( يمكن اختيار اكثر من اجابة ) }
\end{aligned}
$$

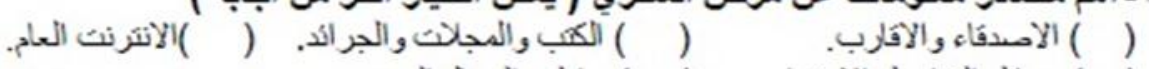

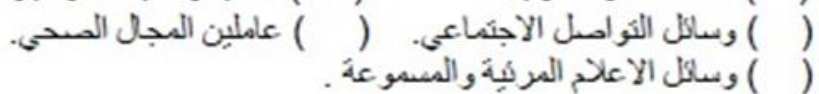

